\title{
Accountability Values for the Performance in Private Islamic University
}

\author{
Wa Ode Rayyani ${ }^{1}$, Hannani ${ }^{2}$ \\ Universitas Muhammadiyah Makassar, IAIN Parepare \\ Email: waode.rayyani@unismuh.ac.id, hannani@stainparepare.ac.id
}

\begin{abstract}
The study aims to reveal the values of performance accountability in private Islamic universities. Type of qualitative research was used in this study by reviewing literature in the context of private Islamic universities. The three objects in this study were Universitas Islam Indonesia, Universitas Muslim Indonesia, and Universitas Muhammadiyah Yogyakarta. The result of this study revealed that the private Islamic universities are promoting Islamic values in their performance accountability. The accountability value of a private Islamic university includes trust in work, which consists of professionalism, honest, worship and charity deeds as well as exploring the religion and professions for understanding the value of religious ordinances and diligently working.
\end{abstract}

Keywords. Private Islamic University, Accountability, Performance, Value

\section{A. INTRODUCTION}

University is defined as a unit of education for higher education organizers. It is a college consisting of a number of faculties that organizes scientific and professional education in a number of specific disciplines. According to Law No. 20 of 2003 article 19 paragraph 1 that "referred to the college is a level of education after secondary education includes diploma programs, scholars, masters, specialists, and doctors organized by 
universities". Becher stated that college or university is a diverse and specific collection of disciplines ${ }^{1}$.

Universities in Indonesia consist of public and private colleges. As called, the state university is a college organized by the government, while the private are organized by private parties. In Indonesia, colleges have many varieties and forms, such as academics, institutes, polytechnics, and universities. The kind of education is held ranging from academic education, profession and vocations. Level education Program, ranging from Diploma 1 (D1), Diploma 2 (D2), Diploma 3 (D3), Diploma 4 (D4), undergraduate (S1), specialist, Magister (S2) and doctoral (S3).

The long-term strategy of the higher education system began in 19751985 through the long-term development of higher education Framework (KTTPJ) issued by the Directorate General of Higher Education. This strategy confirms a strong relationship between national and regional education and development. The success of the university is determined by the ability of the academic staff to respond to changes on an energetic basis ${ }^{2}$. Colleges are one of the national education subsystems. Its existence in the life of the nation and the country plays an important role through the application of Tri Dharma colleges, i.e. education, research, and community service. Law number 20 of 2003 on the national education system mentions that colleges are obliged to conduct education, research, and community service.

Colleges have a very important role in encouraging the advancement of a nation. College is a nation's container to educate its human resources to be skilled people and ready to build a country in the field. The provision of the given is not only the ability of thinking, but also the skills and wisdom of souls.

The existence of higher education is more increasing. This was triggered by one of them by the increasingly community's awareness of the importance of

1 V. L Meek, \& Wood, F.Q, "Higher Education Governance and Management, an Australian Study, Evaluations and Investigations Program, Higher Education Division", (Canberra: DETYA, 1997)

${ }^{2}$ P. Ramsden, "Leading Academics". (Buckingham: Society for Research into Higher Education and the Open University Press, 1998). 
education to the top level. However, the growing population of college growth has not been fully coupled with quality improvement. Public universities almost entirely occupy positions as quality colleges in Indonesia. While the private colleges are capable of being in the same position, at least ' approaching ' the State College in terms of quality, is a well established private college. Established in terms of age, funding, experience in the academic field, and established in management, both the management of the college, as well as the management of the foundation or organization that oversees the universities. The new College of corn, still requires long struggles and is not easy in realizing and solidify its pace to become a college of quality.

The root of the problem is still low quality of the college in Indonesia is not yet an ethical education, the loss of high school idealism, so that the remaining is commercialization, not strictly the government in cracking down the universities that violate the rules, the cost of higher education made so low for the purpose of attracting more students ${ }^{3}$. As a result, many colleges operate at the same moment, taking advantage of the high market demand for college existence.

University should graduate human resources who have noble morality and strong character. ${ }^{4}$ The college is a science and technology development institution that puts it in a strategic position in its efforts to improve the competitiveness of the nation. This function also provides burden and social responsibility of the college to the stakeholders, because the existence of the university is also a role in the development and social change process that occurs in the community. The college is built with quality, wisdom, and a sense of responsibility. Because the college is the establishment of nation children. The formation of his mindset, the formation of his personality, the formation of his skills. If in that process, the college is dry with spiritual values and wisdom, so what will the output of human resources someday?.

${ }^{3}$ B. Frensidy, "Persaingan Perguruan Tingi Indonesia : A Lossers' Game", Jurmal Usahawan No. 08 TH XXXVI, 2007.

${ }^{4}$ M.Alie, "Upaya Menjawab Masalah Pendidikan Tinggi di Indonesia. Refleksi Akhir Tahun 24 Desember 2013”. Website:marzukialie.com, 2013. 
Many studies, with the same basis only within the scope of the religious organization in general. Accountability at private Islamic colleges states that most of the private Islamic colleges are still unaccountable ${ }^{5}$. The challenges faced by Islamic universities, both private and state nowadays are good governance issues, characterized by transparency and accountability.

\section{B. METHOD}

This research is qualitative. The literature study was conducted by analyzing the largest private campuses in Indonesia, namely Universitas Islam Indonesia, Universitas Muslim Indonesia, and Universitas Muhammadiyah Yogyakarta. The documentation method is done to obtain data related to the research. Having data are acquired, analysis techniques are performed using content analysis.

The main focus in this study is the overview of the accounting of private Islamic campuses. Data obtained from a variety of sources that use various data collection techniques (triangulation), and carried out continuously until the data is saturated. Data is indirectly obtained from the source. The data can be a record or literature necessary for this study. In addition, developed academic literature is also used as a supporting in this study.

\section{LITERATURE REVIEW}

The monetary crisis that struck Indonesia in 1998 has shed public confidence in government bureaucracy in the context of government organizing oriented to the welfare of the people. This crisis not only shows that the wheel of government in the New Order era is far from the disclosure of adequate information access to the community as a stakeholder. In such difficult conditions, not very few public ones (as a consequence of it), turned into a pragmatic society and opportunistic.

${ }^{5}$ A. Rusdiana, "Akuntabilitas Perguruan Tinggi Islam Swasta". Jurnal Akuntansi, Vol. XXVIII, No. 3: 455-468, 2013. 
This crisis became the culmination of community demands on the enforcement of accountability in the governance process. The weak enforcement of transparency and accountability forced the government to continuously reform in order to better restore the financial condition of Indonesia, as well as restore the public confidence level against the government. This is the point where transparency and accountability become a central issue in governance, especially in the context of its financial management. The demands for enforcement of transparency and accountability are aimed at creating governance with good corporate governance and good government governance.

In its development, the idea of good corporate governance was adopted into other governmental organizations, namely universities. This concept is known as good university governance. One of the objectives of the adoption of good corporate governance concept into the college area is to improve the quality and quality of the high struggle itself. Good University governance itself at the level of its implementation puts some basic values, among others, accountability, transparency, responsibility, independence (in decision making), fair, quality assurance and relevance, effectiveness and efficiency ${ }^{6}$.

A literal accountability is interpreted as a state to be accounted for or a state to be asked for accountability ${ }^{7}$ or in adjectives called accountable which is defined as responsibility ${ }^{8}$. Accountability is the proper functioning of all components of the company's activities, according to their respective duties and authorities ${ }^{9}$.

${ }^{6}$ R.Z, Tamin, "Governance Perguruan Tinggi. Makalah disampaikan dalam Workshop Penguatan dan Pemberdayaan Kelembagaan Perguruan Tinggi", (Direktorat Kelembagaan dan Kerjasama Ditjen Pendidikan Tinggi, Jakarta, 2014)

7 P. Salim, "Kamus Besar Bahasa Indonesia”, (Jakarta: Balai Pustaka, 1991), pp. 71

${ }^{8}$ M, Kholmi, "Akuntabilitas dan Pembentukan Perilaku Amanah", Jurnal Studi Ekonomi Islam Vol. 15 No. 1: 63-72, 2012, pp. 66.

9 T. Suherman, "Penelitian Masalah Hukum tentang Penerapan Good Corporate Governance pada Dunia Usaha", (Badan Pembina Hukum Nasional Departemen Hukum dan Hak Asasi Manusia, 2007) pp. 35. 
Accountability is a manifestation of the responsibility of a person or organizational unit in managing the resources given to him and mastered in order to achieve the objectives. Triyuwono sees the concept of accountability in the context of sharia accounting ${ }^{10}$. The position of accountability becomes "soul" or becomes the basis of ' ethics ' of (on) the provision of accounting information. Accountability terminology as follows ${ }^{11}$. Accountability is a report that provides an explanation of the actions or activities undertaken. Second, give and raise the reason that the action is in accordance with the prevailing standards. Third, as a form of responsibility on various consequences arising. Based on the Heim explanation, it can be said that accountability is a written report containing explanations of the consequences posed for the activities undertaken, and the report must be based on the prevailing standards.

The principle contained in some of the above accountability sense is that the public has the right to know the policies taken by the parties given the trust. These policies are contained in a form of media accountability, which is a report of accountability in it also includes practical practices of the giver of responsibility in obtaining information, either directly or indirectly. Therefore, accountability will develop well in an environment that prioritizes openness, transparency and democracy, and freedom of opinion. There are two types of accountability $^{12}$, i.e. vertical accountability, is an accountability fund management to employers, such as: central Government Accountability to the legislative and horizontal accountability. Examples of horizontal accountability are accountability to the local legislative and the people. While the State Administration Institute states that accountability according to its type can be

\footnotetext{
10 Iwan Triyuwono, "Perspektif, Metodologi dan Teori Akuntansi Syariah", Edisi Satu, (Jakarta : PT Rajagrafindo Persada, 2006)

11 M, Heim, M. "Accountability in Education." (unpublished paper submitted to the Hawai'i Department of Education in partial fulfillment of professional improvement leave requirements). Honolulu, HI: Hawai' $\mathrm{i}$ State Department of Education, Office of the Superintendent, 1995.
}

${ }^{12}$ Mardiasmo, “Akuntansi Sektor Publik”,(Yogyakarta: Andi Offset, 2005), pp. 134. 
distinguished by internal accountability and external accountability ${ }^{13}$. External accountability the accountability of a person to God according to his religion and belief in what he is doing. It can also be said that external accountability is a person's spiritual accountability. While internal accountability is a person's responsibility to the environment, both the formal organization (superiors) and the community environment. The accountability of a person to his Lord is essentially the essence of true accountability. If one realizes that his responsibilities are the mandate that is deposited to him, then that person will carry out his responsibilities in the most appropriate.

Samuel Paun has different opinions on the types of accountability ${ }^{14}$. He said accountability differentiated from democratic accountability, professional accountability (professional accountability) and accountability based on legal (legal accountability). In the type of democratic accountability, it is described that the Government is accountable for its performance and all its activities to political leaders. In this context, the implementation of accountability is carried out in a level from the lower leadership to the hierarchy of high levels of the President and Consultative Council. While in professional accountability is intended experts, professionals and technocrats who carry out their duties based on the norm and profession standards for the benefit of society. As for the legal accountability, that any public service officer can be submitted to the court when they fail and are guilty in carrying out their duties as expected by the community.

From the opinion above reflects that type of accountability is very diverse. But it has the same obligation, responsibility, goals and objectives for the success of an organization. The accountability that is carried out optimally with the participation of all parties is expected to create a trustworthy and highquality organization.

${ }^{13}$ Lembaga Administrasi Negara. "Pedoman Penyusunan Laporan Akuntabilitas Kinerja Instansi Pemerintah"., Jakarta, 2000. 102.

${ }^{14}$ Tjahya Supriatna, "Manajemen Pemerintahan Daerah", (Bandung:IPDN, 2013), pp. 
Each organization certainly has the objectives to be achieved. In the organization, leaders are tasked with making strategic decisions that can be implemented to achieve their objectives. The performance of an organization depends on the ability to achieve that goal.

Performance is a concrete, observed, and measurable achievement ${ }^{15}$. From this view it can be concluded that the success of a performance depends on how management is able to manage its company in a real and measurable. Speaking of something "measurable", of course the size is a number that can be assessed and compared. In this case, the company generally uses numbers in the financial statements to measure the success of its performance. Financial statements as a result of an accounting process are used as information materials for decision making and planning.

Performance is the achievement level of results or "the degree of accomplishment". In other words, performance is the level of achievement of organizational objectives. So, it can be said that performance is a level of achievement of the implementation of certain tasks, in order to realize the objectives of the organization ${ }^{16}$. Performance is a condition or achievement that must be known and informed to certain parties to determine the level of achievement of a unit of work unit associated with the vision of an organization and to know the positive and negative impacts of a policy taken. This achievement is a view of the organization in carrying out its activities.

Effective performance assessment, there are approximately two key requirements required, namely (1) the presence of performance criteria that can be measured objectively; and (2) the existence of objectivity in the evaluation process ${ }^{17}$. The vision statement of the organizational mission is fundamental in

15 P. Irawan, P. "Analisis Kinerja : Panduan Praktis Untuk Menganalisis Kinerja Organisasi, Kinerja Proses dan Kinerja Pegawai”. (Lembaga Administrasi Negara, Jakarta, 2002), pp. 11

16 J.L Gibson., Ivan Cevich \& Donelly, "Organisasi dan Manajemen: Perilaku, Struktur dan Proses", Terjemahan. (Jakarta : Erlangga, 2003)

${ }^{17}$ F. C Gomes, “Manajemen Sumberdaya Manusia.” (Yogyakarta: Andi, 2003). 
carrying out all activities in it. Mission vision is an important element that supports the success of an organization related to its role in measurement and performance assessment, as well as a performance improvement material for the next period. Like the definitions given by Osborne that performance was the level of achievement of an organizational mission ${ }^{18}$. Performance is defined as the extent to which the Organization is capable of achieving its mission. Thus the State administration agency mentioned that performance is an overview of the level of achievement of the implementation of an activity/policy in realizing the objectives, objectives, mission and vision of the Organization.

It can be concluded that the sense of performance contains substance achievement of organizational work. Performance is a reflection of the results achieved by a person or group of people, in accordance with the vision of a defined mission. Achieving a defined mission vision is the objective of an organization. And in the process of achievement, it is necessary to make a measurement on the achievement of work that has been and will be done. So that it can be known to the extent that the achievement of the objectives is carried out, what are the challenges and obstacles in the process, and how to overcome it. Performance is the answer to whether or not an organizational objective has been established. The results of these performance measurements will be useful for planning the next period.

\section{RESULT AND DISCUSSION}

Accountability in colleges is not limited to financial management alone. College accountability includes several things, namely 1) upward accountability that demonstrate traditional relationships in the form of subordinate responsibilities to superiors including procedural, bureaucratic, legal and vertical accountability; 2) downward accountability, focusing on the responsibility of leadership towards subordinates in decision making or the accountability of the college's participation in universities; 3) Inward accountability, centered on the

18 D.Osborne, "Organizational Theory an Intergrated approach". (United States : Perseus Book Publisshing, 1990). 
action of teaching staff in applying various professional and ethical standards, referred to as professional accountability; and 4) outward accountability, is intended to be related to outside customers, stakeholders, supporters (donors) and ultimately to the community in the broadest sense.

The private Islamic universities in Indonesia are not under the responsibility of the Ministry of Religious Affairs, but are managed by Islamic organisations. As well as state universities, Islamic private colleges are also required to further improve their role, while retaining the distinctive characteristics of its own. Because ideally a college of Islam is an educational institution that pays attention to its quality while retaining its specifications, as a college of Islam, namely that education in Islamic colleges is more emphasis on religious education. With the aim that the higher education of Islam can produce professional graduates, but also keep the values of Islamic religion. Islamic values attached to Islamic private universities are the main characteristic that is owned. This characteristic is the identity of a private college of Islam as well as a differentiator from other colleges.

Value is a principle, standards include also qualities that have benefits. The value interpreted a kind of conviction, which then became the standard or basis in choosing the action to be performed. Speaking of value is essentially choosing between two things about which is good and which is not good to do. In Islam, the value is the standard for assessing an action to be true or false. All human relationships are always governed by Islamic values based on the concept of al-Qur'ân and Sunnah that humans are given high potential to do good to themselves and society. The honor on the true side of God is the way of life. ${ }^{19}$

The actualisation of a private college of Islam, in his attempts to keep survive and develop himself experienced many changes. In addition, Muslim private colleges consider changes and transitions in social, economic and

${ }^{19}$ Faizi, Waqar-un-Nisa et al.., "The Role of Different Factors in the Promotion of Islamic Values among the Students of Secondary Level In Karachi, Pakistan". International Journal of Academic Research in Business and Social Sciences, Vol. 1, No. 3 (Oktober, 2011). pp. 221. 
political. Islamic education is generally a conflict between tradition and modernity ${ }^{20}$. In the midst of these conditions, private universities of Islam also continue to develop themselves in order to improve their quality, as well as the demands and responsibilities that are in the state of a higher education institution.

The working in Islam is seen as worship. In Islam, working is actualization of faith and fear to reach Taqwa Allah Swt. Islam creates performance as a foundation of value that is human and as a form of accountability, as explained in the Qur'an Al-Najm: 39 "And that there is indeed no reply to that person but a reply to what is cultivated".

Islamic values regarding the performance above are implied in the vision and mission of a private college of Islam. Among them the Islamic University of Indonesia, where the vision is "the realization of the Islamic University of Indonesia as Rahmatan Lil'alamin, has a commitment to perfection (excellence), treatise Islamiyah, in the field of education, research, community service and Da'wah, university level of quality in developed countries"21.

Universitas Muslim Indonesia, with its vision of "creating UMI as an educational institution and a superior da'wah, the quality of Islamic \&, giving birth to human beings Amaliah, scientific and religious, and Berakhlaqul Karimah, especially related to the development of IPTEKS (science, Technology, and arts) in the framework of Islamic Syiar and fight for the importance of Ummah as a manifestation of devotion to Allah Subhanahu Wa ta'ala" (UMI, 2010-2014)22. The Universitas Muhammadiyah Yogyakarta has the following vision: "To be a university that excels in the development of science

20 S.S., Husain, \& Ashraf, S.A, "Crisis in Muslim Education", (Hodder and Stoughton \& King Abdulaziz University. Jeddah, 1979).

${ }^{21}$ Rencana Strategis Universitas Islam Indonesia 2010-2014. Penguatan Tata Kelola, Kualitas Akademik dan Keunggulan Berbasis Nilai-nilai Keislaman menuju World Class University. pp. 2

22 Rencana Strategis Universitas Muslim Indonesia. 2010-2014. Berilmu Amaliah, Beramal Ilmiah dan Berakhlakul Karimah 
and technology, based on Islamic values for the benefit of the People" (UMY, 2009-2014) 23 .

From the overall vision it is seen that the vision is the spirit of responsibility entrusted to the college to maximize performance in the achievement of its objectives. The responsibility is not only for stakeholders, but also in the wider sphere of responsibility for the nation and nation. The highest is the responsibility of the one true God. In order to achieve this, well-arranged performance is expected to be a way of achieving hope in the vision of the mission.

Three ways to realize the good performance, namely work based on Taqwa, climate and work atmosphere is calm and conducive, and supported by science related to the field of work, and always trying to add to the knowledge. A job based on the intention of Takwa, seeking Taqwa is an implementation of the expressions that we often hear, that work is worship. Working for a better livelihood is an obligation. The work is liked by God and His messenger when the work is carried out sincerely by the intent of seeking his ridho.

In the value of Islamic private universities, there are several dimensions of Islamic performance which includes the trust in the work, which consists of professionalism, honest, worship and charity deeds and deepen the religion and profession of understanding the value of religion and diligent work. As for some elements in conducting performance assessment of business activities, the first thing is the intention of working because of God. In the work, we must give the sincerity and the motivation to work is to seek the world's luck and the hereafter. It is also required to apply the principle of efficiency and benefits while preserving the environment, as well as seeking a balance of wealth with worship, and after success in working, should be grateful to Allah SWT for all the delights that have been given.

\section{E. CONCLUSION}

A good and comprehensive understanding of the Islamic values associated with performance will create a good college accountability. The

${ }^{23}$ Rencana Strategis Universitas Muhammadiyah Yogyakarta. 2009-2014. 
accountability based on Islamic values is also practiced in private Islamic universities that promote Islamic accountability in achieving their work. Every Islamic-based organization will always realize the nature of management so that it will always be tawadhu in working. Thus, the Islamic private universities are able to reflect the accountability of performance and values that are Islamic. The values of Islam in private colleges are implied in the vision and mission of a private Islamic universities. The value of Islam is the spirit of responsibility entrusted to the universities to maximize performance in the achievement of its objectives.

\section{REFERENCES}

al-Qur'an al-Karim

Alie, M. Upaya Menjawab Masalah Pendidikan Tinggi di Indonesia. Refleksi Akhir Tahun 24 Desember 2013. Website:marzukialie.com, 2013.

Faizi, Waqar-un-Nisa et al., The Role of Different Factors in the Promotion of Islamic Values among the Students of Secondary Level In Karachi, Pakistan. International Journal of Academic Research in Business and Social Sciences, Vol. 1, No. 3 (Oktober, 2011).

Frensidy, B. Persaingan Perguruan Tingi Indonesia : A Lossers' Game. Jurmal Usahawan No. 08 TH XXXVI, 2007.

Gibson, J.L., Ivan Cevich \& Donelly. Organisasi dan Manajemen: Perilaku, Struktur dan Proses. Terjemahan. Jakarta : Erlangga, 2003

Gomes, F. C. Manajemen Sumberdaya Manusia. Yogyakarta: Andi, 2003.

Heim, M. "Accountability in Education." (unpublished paper submitted to the Hawai'i Department of Education in partial fulfillment of professional improvement leave requirements). Honolulu, HI: Hawai'i State Department of Education, Office of the Superintendent, 1995

Husain,S.S., Ashraf, S.A. Crisis in Muslim Education. Hodder and Stoughton \& King Abdulaziz University. Jeddah, 1979.

Irawan, P. Analisis Kinerja : Panduan Praktis Untuk Menganalisis Kinerja Organisasi, Kinerja Proses dan Kinerja Pegawai. Lembaga Administrasi Negara, Jakarta, 2002.

Kholmi, M. Akuntabilitas dan Pembentukan Perilaku Amanah. Jurnal Studi Ekonomi Islam Vol. 15 No. 1: 63-72, 2012 
Lembaga Administrasi Negara. Pedoman Penyusunan Laporan Akuntabilitas Kinerja Instansi Pemerintah. Jakarta, 2000.

Mardiasmo. Akuntansi Sektor Publik. Yogyakarta: Andi Offset, 2005

Meek, V.L. and Wood, F,Q. Higher Education Governance and Management, an Australian Study, Evaluations and Investigations Program, Higher Education Division, DETYA, (Canberra: DETYA). Internet http://www.deetya.gov.au/highered/repts.htm, 1997

Osborne, D. Organizational Theory an Intergrated approach. United States : Perseus Book Publisshing, 1990

Ramsden, P. Leading Academics. Buckingham: Society for Research into Higher Education and the Open University Press, 1998.

Rencana Strategis Universitas Islam Indonesia 2010-2014. Penguatan Tata Kelola, Kualitas Akademik dan Keunggulan Berbasis Nilai-nilai Keislaman menuju World Class University.

Rencana Strategis Universitas Muhammadiyah Yogyakarta. 2009-2014.

Rencana Strategis Universitas Muslim Indonesia. 2010-2014. Berilmu Amaliah, Beramal Ilmiah dan Berakhlakul Karimah.

Rusdiana A. Akuntabilitas Perguruan Tinggi Islam Swasta. Journal Akuntansi, Vol. XXVIII, No. 3: 455-468, 2013.

Salim, P. Kamus Besar Bahasa Indonesia. Jakarta: Balai Pustaka, 1991.

Suherman, T. Penelitian Masalah Hukum tentang Penerapan Good Corporate Governance pada Dunia Usaha. Badan Pembina Hukum Nasional Departemen Hukum dan Hak Asasi Manusia, 2007.

Supriatna, Tjahya. Manajemen Pemerintahan Daerah, Bandung:IPDN, 2013

Tamin, R, Z. Governance Perguruan Tinggi. Makalah disampaikan dalam Workshop Penguatan dan Pemberdayaan Kelembagaan Perguruan Tinggi. Direktorat Kelembagaan dan Kerjasama Ditjen Pendidikan Tinggi. Jakarta, 2014.

Triyuwono, I. Perspektif, Metodologi dan Teori Akuntansi Syariah. Edisi Satu. Jakarta : PT Rajagrafindo Persada, 2006. 